\title{
CAD・CG を利用した空間デザイン表現の演習教育
}

The Class of Design Practice for Space Design using CAD/CG

下川 雄一 Yuichi SHIMOKAWA

川崎 寧史 Yasushi KAWASAKI

宮下 智裕 TOmohiro MIYASHITA

\section{概要}

「空間メディア」は金沢工業大学建築系の 3 年生を対象と した演習授業科目である。この科目は設計表現の制作に対す る $\mathrm{CAD} \cdot \mathrm{CG}$ の利用に加え，さまざまなブレゼンテーション 技法の理解と操作技能の習得を目的としている. 建築系の $\mathrm{CAD} \cdot \mathrm{CG}$ 利用は, デザイン表現を前提する意味で, 他の工 学分野における $\mathrm{CAD} \cdot \mathrm{CG}$ による視覚化表現とは大きく異な る特徵を持つ. したがって, その教育においては各種ッール の操作方法と並行して, 美的なデザインやプレゼンテーショ ン制作に対する指導が必要となる. 2004年度の授業では $\mathrm{CAD} \cdot \mathrm{CG}$ を用いた空間デザインの高度な表現技法の教育向 上を目指して, 新しいソフトウェア環境とステップアップ式 の課題制作方式を導入するとともに, 多人数教育に対応した 授業運営方式を取り入れた．本稿の前半では，「空間メディ ア」のねらいや授業運営方式を紹介した後, 具体的な指導や 課題の内容を述べている. 後半では, 最終課題で提出された 学生の作品を紹介した後, 2004年度に導入した新しい試みの 教育成果について報告する.

キーワード：コンピュータ・グラフイックス, CAD, 空間 デザイン, ブレゼンテーション

\section{Abstract}

The class of "Space Media" is opened for the third grade of the architecture course. This class is the practice for learning of CAD (Computer Aided Design) and Image processing CG (Computer Graphics) technology for architectural design. The $\mathrm{CAD} / \mathrm{CG}$ use in the architecture course has a character as a media of design presentation. Therefore, it aims at learning of not only the drawing skill but also the presentation skill as well. It was started from 2004 that using new some softwares, step-up reports for design theme and management rules of class corresponding a large number of student. Compared with the class of former year, students' level of design presentation has got up clearly in the class of 2004. In this paper, we report aims of "pace Media" and abstracts of the class first, and showed some students' final reports of space object design next. Consideration about the effectives of our new trial is reported finally.

Keywords : Computer Graphics / Computer Aided Design / Space design / Presentation

\section{1.はじめに}

建築設計者·技術者の基本スキルとして，建築や空間 に対する表現力の向上は, 建築分野での情報利用に対す る大きな教育的テーマと考えられる。しかし，これまで の建築分野における情報利用教育は, 図形処理の操作技 能（オペレーション）の習得に重きを置いてきたため, デザイン力を養う設計演習や他の専門教科科目との密接 な関連を必ずしも持ち得ていない。

この問題に対しては，すでにいくつかの教育的試みが 報告されている。例えば，阿部・吉田 ${ }^{[1]}$ は図学実習を対 象に，「体験的授業」の形式でキャンパス建築の実測と 3 次元 CGッールによる計画表現を連携させた演習授業 を実施している。ここでは穾空間の把握と図法の理解を 体験的に行わせ, 問題発見型の建築系図学教育を成功さ

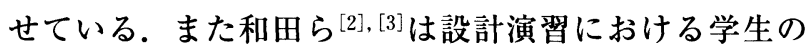
「場面」設定に着目し, 学生のスケッチとこれに対応した コメント（設計教育モジュール）に対するプロトコル分 析を行っている，さらに「場面」に対するスケッチと 3 次元 $\mathrm{CAD}$ の利用比較を行い, $\mathrm{CAD}$ による複数の空間操 作や疑似体験が, 設計教育に有効であるとの結論を得て いる.この他, 最近では Webによる双方向型の協調設 計 ${ }^{[4]}$ などが IT 設計教育として盛んに試行されている.

以上のような既往研究に対して, 本稿の「空間メディ ア」科目は, 3 次元 $\mathrm{CAD} \cdot \mathrm{CG}$ を利用して, 空間デザ インのプレゼンテーション技法を習得させる演習科目で ある。ここでの狙いは，デザイン表現の思考と $\mathrm{CAD}$. $\mathrm{CG}$ 操作を感覚的に直結させることであり，デザイン表 現の十分なイメージを持って必要な表現技法を学べるよ う配慮している，そのため，一つのデザインテーマを目 標に 3 次元 $\mathrm{CAD}$ と画像処理ソフトの演習操作を行って おり, 課題内容もこの目標に沿ってステップアップ式に 組み立てている。先述した阿部・吉田 ${ }^{[1]}$ も 3 次元 $\mathrm{CG} に$ よる建築モデリングと画像処理を用いた修景を連動させ ており，教育手段としての共通点は見られる．ただし，

「空間メディア」は建築実体の把握や図法の理解などの 
教育意図は持っておらず， 3 次元 $\mathrm{CAD} \cdot \mathrm{CG}$ による感 覚的な空間デザインと表現効果の相乗を目的としたカリ キュラム内容となっている.

\section{2.「空間メディア」の経緯と概要}

金沢工業大学建築系の授業科目「空間メディア」は, 図面制作としての建築 $\mathrm{CAD}$ 演習（2 年生対象）のアド バンス授業として開講される選択授業である。 その内容 は, 3 次元 $\mathrm{CAD}$ を利用したデザイン演習と図面制作で あり, 本来の CAAD (Computer Aided Architectural Design）の基本技能を習得させるものである. 開講時 間は週 3 コマ・11週であり, 第10週に最終課題の提出, 最終週で課題講評と自己点検を行っている. 2003年度ま

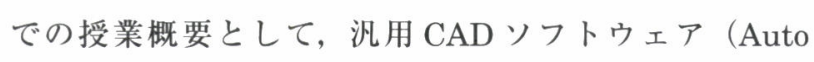

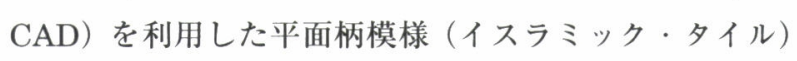
のデザイン，画像处理ソフトウェア（Photoshop Elements）を利用した空間イメージの表現を中間課題 として実施し, 最終課題として CAD と画像処理を適宜 組み合わせ簡易な室内空間のプレゼンテーション演習を 実施した (計 3 課題).

以上の授業内容について, 次のような問題が学生側か ら指摘され，さらには教員側でも自発的に認識できた. まず，(1)ソフトウェア環境としては，従来使用の $\mathrm{CAD}$ ソフトの操作手続きは 3 次元の直感的なデザイン操作に は十分対応していないこと, 四面レイアウト機能が弱く プレゼンテーション紙面の作成が難解なこと, (2)ハード ウェア環境としては, カラースキャナーや A 1 版プロッ ターなどの高度な入出力機器の整備充実が望まれるこ と, $\mathrm{CAD}$ 室の利用時間を延長すること, (3)演習内容と
しては, デザイン課題の内容に相互関連がなく表現技能 のステップアップを十分実感できないこと，などがあっ た。2004年度は予算要求の機会にも恵まれ, 以上の問題 について施設整備および授業内容の見直しの両面から対 処することとなった。

\section{2004年度「空間メディア」の授業運用 \\ 3.1. 授業概要と施設環境}

開講時期および時間は変更なく, 建築系 3 年生を対象 として週 3 コマ ( 1 コマ60分), 最終課題提出(第10週) と自己点検授業（第11週）を含めて全11週の授業科目で ある. 学内共有の $\mathrm{CAD}$ 室で講義と演習を行っている.

$\mathrm{CAD}$ 室は分割して 2 室 $(\mathrm{A} \cdot \mathrm{B}$, 図 1 ) 利用でき, $\mathrm{CAD}$ 室 $\mathrm{A}$ は CAD ソフトVectorWorks, SketchUPなどを利 用した講義・ $\mathrm{CAD}$ 演習に, また $\mathrm{CAD}$ 室 $\mathrm{B}$ は画像処理 ソフトPhotoShop Elementsを利用した講義· CG 演習 (画像処理演習) に利用する。表 1 に示す通り, $\mathrm{CAD}$

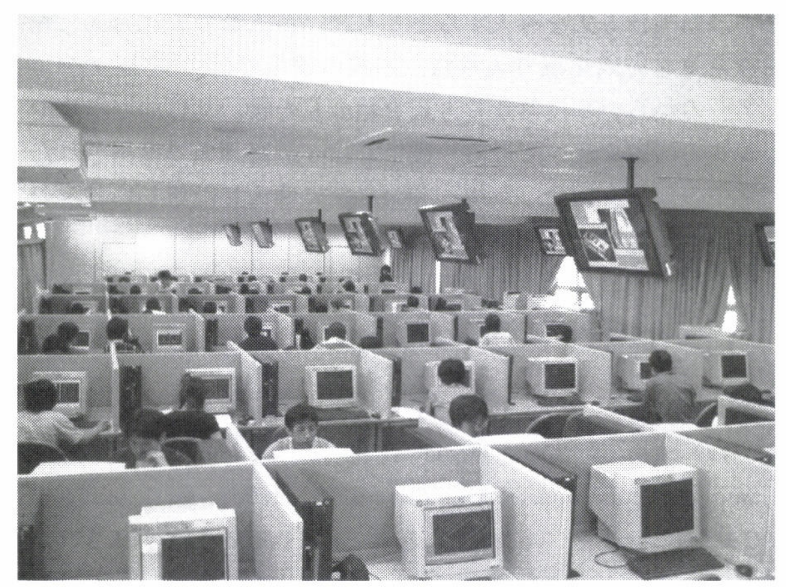

図 1 CAD 室授業風景

表 1 CAD 室の設備（2004年度）

\begin{tabular}{|c|c|c|}
\hline & CAD 室A（CAD 演習に利用） & CAD 室 B（CG 演習に利用） \\
\hline パソコン & $\begin{array}{l}\text { 教員用 PC（Windows× } 1 \text { 台） } \\
\text { 学生用 PC（Windows×80台） }\end{array}$ & $\begin{array}{l}\text { 教員用 PC（Windows× } 1 \text { 台） } \\
\text { 学生用 PC（Windows×80台） }\end{array}$ \\
\hline 資料提示装置 & $\begin{array}{l}\text { 天井吊り下げ型プラズマディスプレイ（12台） } \\
\text { (教員用 PC の画面を表示できる) }\end{array}$ & $\begin{array}{l}\text { 天井吊り下げ型プラズマディスプレイ (12台) } \\
\text { (教員用 PC の画面を表示できる) }\end{array}$ \\
\hline 出力環境 & $\begin{array}{l}\text { レーザープリンター（モノクロ A } 3 \times 6 \text { 台 }) \\
\text { インクジェットプリンター（カラーA } 1 \times 3 \text { 台 })\end{array}$ & レーザープリンター（モノクロＡ３×10台） \\
\hline 入力環境 & & カラースキャナー（A 3 対応 × 2 台 $)$ \\
\hline ソフトウェア & $\begin{array}{l}\text { VectorWorks （汎用 CAD ソフト) } \\
\text { SketchUP ( } 3 \text { 次元 CAD ソフト) } \\
\text { Reals (レンダリング・ソフト) }\end{array}$ & Photoshop Elements（画像処理ソフト） \\
\hline 利用時間 & \multicolumn{2}{|c|}{ 月曜～金曜：午前 $8: 30$ 午後 $7: 00$ 、土曜：午前 $8: 30$ 午後 $1 ： 00$} \\
\hline
\end{tabular}

※上記 2 室は間仕切りを取り外し、1 室として利用することも可能。

※2004年度の授業では Reals（レンダリングソフト）は使用していない。 
表 2 2004年度（左）と2003年度（右）の授業スケジュール

\begin{tabular}{|c|c|c|c|c|c|}
\hline 週 & 形式 & 2004年度 & 週 & 形式 & 2003年度 \\
\hline \multirow{3}{*}{1} & 授業 & $\begin{array}{l}\text { 講義: 空間表現とプレゼンテーション技法 } \\
\text { CAD 演習 } 1: 2 \text { 次元 CAD 操作の演習 }\end{array}$ & \multirow{3}{*}{1} & 授業 & $\begin{array}{l}\text { 講義: 空間表現とプレゼンテーション技法 } \\
\mathrm{CAD} \text { 演習 } 1: 2 \text { 次元 } \mathrm{CAD} \text { 操作の演習 }\end{array}$ \\
\hline & 課題 & *課外時間の宿題なし & & 課題 & *課外時間の宿題なし \\
\hline & 環境 & VectorWorks $の 2$ 次元作図機能 & & 環境 & AutoCAD の 2 次元作図機能 \\
\hline \multirow{3}{*}{2} & 授業 & $\begin{array}{l}\text { 講義 : CAD による立体的な空間表現 } \\
\mathrm{CAD} \text { 演習 } 2: 2 \text { 次元 } \mathrm{CAD} \text { の基本操作 }\end{array}$ & \multirow{3}{*}{2} & 授業 & $\mathrm{CAD}$ 演習 $2 ： 2$ 次元 $\mathrm{CAD}$ の基本操作 \\
\hline & $\begin{array}{c}\text { 課題 } \\
1\end{array}$ & $\begin{array}{l}\text { [スペースオブジェのデザインと図面作成 }] \\
\text { スペースオブジェのデザインを検討し, その屋根伏 } \\
\text { 図・立面図を } 2 \text { 次元 CAD で作成 }\end{array}$ & & $\begin{array}{c}\text { 課題 } \\
1\end{array}$ & $\begin{array}{l}\text { [タイルパターンのデザイン] } \\
2 \text { 次元 CAD でタイルパターンのデザインを表現 }\end{array}$ \\
\hline & 環境 & VectorWorks の 2 次元作図機能 & & 環境 & AutoCAD の 2 次元作図機能 \\
\hline \multirow{3}{*}{3} & 授業 & $\mathrm{CAD}$ 演習 $3: 3$ 次元 $\mathrm{CAD}$ の操作 & \multirow{3}{*}{3} & 授業 & $\begin{array}{l}\text { 講義 : } 3 \text { 次元 } \mathrm{CAD} \text { による空間表現技法 } \\
\mathrm{CAD} \text { 演習 } 3: 3 \text { 次元 } \mathrm{CAD} \text { の基本操作 }\end{array}$ \\
\hline & $\begin{array}{l}\text { 課題 } \\
2\end{array}$ & $\begin{array}{l}\text { [スペースオブジェのデザインと } 3 \mathrm{D} \text { モデル作成 }] \\
\text { 課題 } 1 \text { で作成したスペースオブジェを } 3 \text { 次元モデル } \\
\text { として作成・検証し, 透視図を組み合わせてレイア } \\
\text { ウトする }\end{array}$ & & 課題 & *課外時間の宿題なし \\
\hline & 環境 & $\begin{array}{l}\text { SketchUP の } 3 \text { 次元モデリング機能 } \\
\text { VectorWorks のレイアウト機能 }\end{array}$ & & 環境 & AutoCAD の 3 次元モデリング機能 \\
\hline \multirow{3}{*}{4} & 授業 & $\begin{array}{l}\text { 講義：画像処理による空間表現 } \\
\text { CG 演習 } 1 \text { : 画像処理の基本演習 }\end{array}$ & \multirow{3}{*}{4} & 授業 & $\mathrm{CAD}$ 演習 $4: 3$ 次元 $\mathrm{CAD}$ の操作 \\
\hline & 課題 & *課外時間の宿題なし & & 課題 & *課外時間の宿題なし \\
\hline & 環境 & PhotoshopElements & & 環境 & AutoCAD の 3 次元モデリング機能 \\
\hline \multirow{3}{*}{5} & 授業 & CG 演習 2： 写真合成によるイメージ表現 & \multirow{3}{*}{5} & 授業 & \begin{tabular}{|l} 
講義：画像処理による空間イメージの表現, \\
様々な CG 技法と映像表現
\end{tabular} \\
\hline & $\begin{array}{c}\text { 課題 } \\
3\end{array}$ & $\begin{array}{l}\text { [写真合成によるイメージ表現 }] \\
\text { 画像処理ソフトで写真合成を行い, 自由な発想でイ } \\
\text { メージ画像を作成する }\end{array}$ & & 課題 & *課外時間の宿題なし \\
\hline & 環境 & PhotoshopElements & & 環境 & ＊使用するソフトウェアはなし \\
\hline \multirow{3}{*}{6} & 授業 & CG 演習 3 : 建築パースと風景の合成 & \multirow{3}{*}{6} & 授業 & CG 演習 1 ：写真合成によるイメージ表現 \\
\hline & $\begin{array}{c}\text { 課題 } \\
4\end{array}$ & $\begin{array}{l}\text { [建築パースと風景の合成 }] \\
\text { 課題 } 5 \text { で周辺環境を含めた建築パースを作成するため } \\
\text { に, 建築物と風景を合成したイメージ画像を作成する } \\
\end{array}$ & & $\begin{array}{l}\text { 課題 } \\
2\end{array}$ & $\begin{array}{l}\text { [写真合成によるイメージ表現 }] \\
\text { 画像処理ソフトで写真合成を行い，自由な発想でイ } \\
\text { メージ画像を作成する }\end{array}$ \\
\hline & 環境 & PhotoshopElements & & 環境 & PhotoshopElements \\
\hline \multirow{3}{*}{7} & 授業 & 講義：レイアウト技法の講義・演習 & \multirow{3}{*}{7} & 授業 & $\begin{array}{l}\text { 講義：画像処理による環境デザインの表現 } \\
\text { CG 演習 } 2 \text { : 建築パースと風景の合成 } \\
\end{array}$ \\
\hline & $\begin{array}{c}\text { 課題 } \\
5\end{array}$ & $\begin{array}{l}\text { [スペースオブジェメパーフェクトプレゼンテーション] } \\
\text { 課題 } 1,2 \text { で作成したスペースオブジェに, 課題 } \\
3,4 \text { 習得したイメージ表現技法を応用し, 魅力 } \\
\text { 的な図面として完成させる }\end{array}$ & & 課題 & *課外時間の宿題なし \\
\hline & 環境 & VectorWorks, SketchUP, PhotoshopElements の連携 & & 環境 & PhotoshopElements \\
\hline \multirow{3}{*}{8} & \multirow{3}{*}{ 授業 } & \multirow{3}{*}{$\begin{array}{l}\text { [課題作成と個別アドバイス] } \\
\text { スペースオブジェのデザインコンセプトを明解かつ } \\
\text { 魅力的に表現するための CAD・CG 利用方法を事 } \\
\text { 例紹介を含めてアドバイス }\end{array}$} & \multirow{3}{*}{8} & 授業 & 講義：ダイアグラムによる空間表現, レイアウト技法 \\
\hline & & & & $\begin{array}{c}\text { 課題 } \\
3\end{array}$ & $\begin{array}{l}\text { [室内空間のプレゼンテーション] } \\
\text { 建築物の任意の室内空間を } 1 \text { つ選び，3次元モデリ } \\
\text { シグと画像処理の技法を組み合わせ，魅力的な図面 } \\
\text { を作成する }\end{array}$ \\
\hline & & & & 環境 & AutoCAD, PhotoshopElements \\
\hline 9 & 授業 & [課題作成と個別アドバイス] & 9 & 授業 & [課題作成と個別アドバイス] \\
\hline 10 & 授業 & 最終課題提出 & 10 & 授業 & 最終課題提出 \\
\hline 11 & 授業 & $\begin{array}{l}\text { 自己点検授業 } \\
\text { 作品講評とアンケート実施 }\end{array}$ & 11 & 授業 & $\begin{array}{l}\text { 自己点検授業 } \\
\text { 作品講評とアンケート実施 }\end{array}$ \\
\hline
\end{tabular}

※[形式］覧の「授業」は授業中に実施した内容，「課題」は課外時間の宿題として課した内容，「環境」は課題作成で用いる作業 環境を表す。 
室 $\mathrm{A}$ には $\mathrm{CAD}$ 関連の作業に対応したソフトウェアや出 力装置が備えられ, $\mathrm{CAD}$ 室 $\mathrm{B}$ には画像処理関連の作業 に対応したソフトウェアや入力装置が備えられている. 特に CAD ソフトはデザイン系学生に対しても操作習得 が平易であり, かつ直感的な 3 次元操作ができること, さらにApple Computerにも普及されていることなどを目的 として, 総合的に選定している.

\section{2. 授業カリキュラム}

授業は執筆者である担当教員 3 名と大学院生のティー チングアシスタント（TA）2名で担当する．例年, 履 修者の数 (200名前後が受講, 履修率約 $80 \%$ ) に対して ソフトウェアの数が足りないため, 前半は履修者を 2 つ のグループに分け，一方のグループが CAD 演習を受け る間，もう一方のグループは CG 演習を受け，途中で内 容を入れ替わる方式となっている。表 2 の2004年度の授 業スケジュールで， 1 ～ 3 週， 4 〜 6 週が入れ替わる形 である。後半はグループに関係なく 2 室を同時に利用 し, 最終課題の制作を進める. 以下, CAD 演習からス タートするクラスを例に, 講義・演習の概要を述べる.

\subsubsection{CAD・CG 演習の概要}

最初の授業では, 授業のねらい, 進め方, 行動目標, 演 習や課題の内容などを説明する，以下に，主な講義内 容, 習得目標, 演習課題の概要を示す.

\section{a . 講義内容}

空間デザインにおいて, 魅力的な表現を行うことの重 要性を述べ，そのために求められる様々な空間表現技法 (図面表現, パース, ダイアグラム, 模型, コラージュ など）について解説し，デザイン表現の感覚を養う必要 があることを事例を示しながら説明する(図 $2(a)(b))$. また，それを実感させるために，手書きによる簡単な付 影の練習も合わせて実施する (図 $2(\mathrm{C})$ ). 更に, 空間デ ザインの提案において最終的にどのような質のものが求 められるか, 具体的なイメージを持たせるために, 前年 度の最終課題の優秀作品を提示する。

b. 習得目標

CAD による建築四面や立体モデル作成, $\mathrm{CG}$ による イメージ処理等の作業はもとより, それらをデザイン検 討に応用し，且つ最終的な紙面プレゼンテーションのた めの $\mathrm{CAD} \cdot \mathrm{CG}$ 併用によるデザイン表現技法を習得す ることを説明する．また，必要に応じて手描きやスキャ ナーによる取り达みとレタッチなども有効であることも 示す.このように,「空間メディア」はメディアミック スによるデザイン表現を重要な教育目的としており, $\mathrm{CAD} \cdot \mathrm{CG}$ を利用した表現の可能性を自発的に探ること
が学生の行動目標であることを説明する.

\section{c. 演習課題}

2004年度は 5 つの課題を害施した。課題 1 〜 で実施 される課題は全て最終課題（課題 5 ）におけるスペース オブジェのデザイン表現に必要な技術やデザイン検討を 行うためのステップとなっており，これは前年度から大 きく改善した点である. 課題 $1 \sim 2$ は CAD 演習内で実 施し， 2 次元 $\mathrm{CAD}$ と 3 次元 $\mathrm{CAD}$ を利用したスペース オブジェのデザインと表現を行う。課題 $3 \sim 4$ は CG 演 習内で実施し, 画像処理ソフトウェアを利用した理想的 な空間のイメージを表現や検証を行う課題を課す，最終 課題はレイアウト技法の講義・演習内で実施し, スペー スオブジェを設置する環境を自由に想定させ，スペース オブジェがつくる外観や空間のイメージを的確に表現さ せるという積み重ね方式となっている(各課題の内容を 表 2 に示す)．以下に CAD 演習, $\mathrm{CG}$ 演習の各内容につ

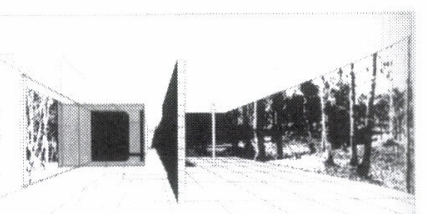

(a)張り込みによる背景合成の事例[5]より引用

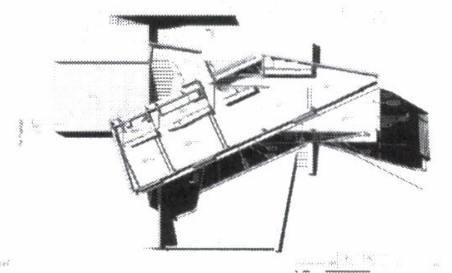

(b)手描きによる付影の事例[6]より引用
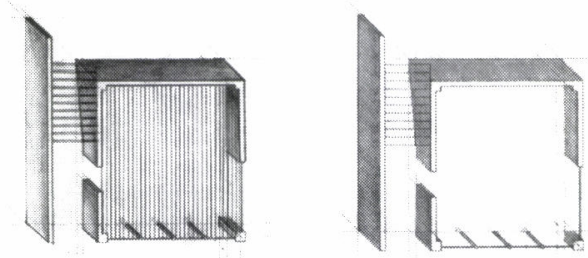

(C)手描きによる付影の練習

図 2 表現技法の理解と練習

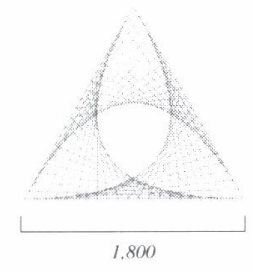

"Space object" suface PLAN ruled surface in regular triangle

図３CAD 演習によるスペースオブジェの図面表現 (課題 1 作品) 


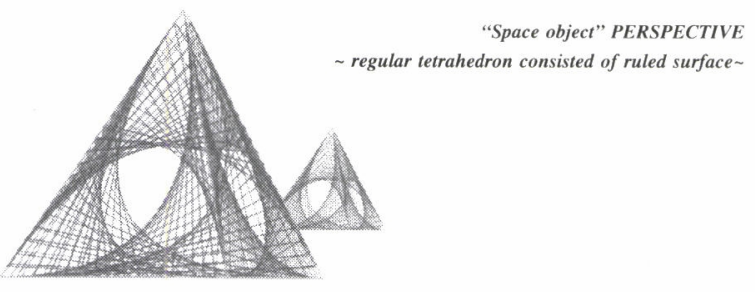

図4 3 次元 CAD によるスペースオブジェの表現

(課題 2 作品)

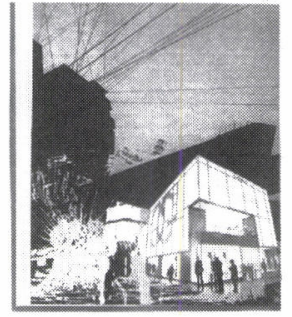

(a)中間課題 3 作品

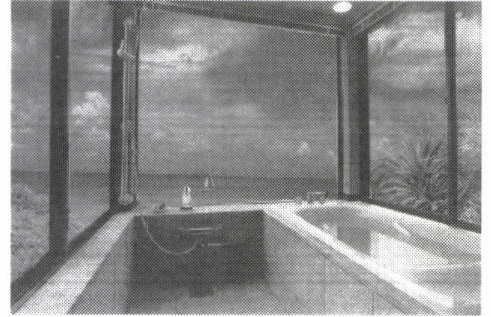

(b)中間課題 4 作品
図 5 CG 演習による空間イメージの表現・確認

いて示す。

\subsubsection{CAD 演習}

$\mathrm{CAD}$ 演習は 3 週間（9コマ）で実施する（表 2 の 1 〜 3 週).ここでの習得目標は次の通り.

(1) 2 次元 $\mathrm{CAD}$ で空間の基本デザインを描ける.

(2) 3 次元 $\mathrm{CAD}$ で立体的に空間を把握・検証できる。

上記(1)に対応する最初の 2 週（6コマ）では，2 次元 の図面作成のための CAD 操作法や図面表現の技法を説 明する。スペースオブジェデザインの課題説明（課題 1) は2 週目で行った。この際, 既存事例の写真画像を パワーポイントで紹介し，学生の創作意欲を掻き立てる と同時に，設計者の意図とそれに対応した表現技法を $\mathrm{CAD}$ の操作を踏まえながら解説し，習得した CAD 操 作技法を応用できるよう促した。また，課題 1 の制作に おいては，人物や樹木のシンボルを立面図内に配置して スケール感や存在感を出す, 空間の雲囲気に応じて線の 強弱や影付けを行う，といった点に留意するよう説明し た. 図 3 に課題 1 で提出された作品のサンプルを示す.

上記(2)に対応する残りの 1 週（3コマ）では，パース 制作のための 3 次元モデリングの操作方法や立体的な空 間表現の技法を説明する。ここで実施する課題 2 は課題 1 のスペースオブジェデザインの継続であるが，課題 1 で提案したデザインをよく吟味した上で，3次元的思考 に基づくデザイン変更を皘極的に行うよう奨励してい る. 課題 2 の説明においては, モニター上で 3 次元モデ ルを操作してみせながら，3 次元的にデザイン検討を進 め，立体感のあるデザインを施すこと，空間を最も印象 的に見せる視点・視角を探し出すこと，等の重要性を示
した. 図 4 に課題 2 で提出された作品のサンプルを示 す。優秀作品は制作者本人に発表させ, 使用したツール や工夫した点を説明させることにより授業全体での知識 の共有を図っている。

\subsubsection{CG 演習}

$\mathrm{CG}$ 演習は CAD 演習同様，3 週間（9コマ）で実施 する $(4 \sim 6$ 週). 建築物は建設される前に図面を引 き，その建物の姿や内部空間を表現しなくてはならない ため，現実の風景と模型写真や CG 合成する手法が頻 繁に用いられる。これを踏まえ，習得目標を次のように 設定している.

(3)画像処理で空間のイメージを膨らますことができる. (4)画像処理で空間のイメージを確認・検証できる.

CG 演習の 1 週目では，画像処理による空間表現の基 本事項や作品例などを紹介し，画像処理ソフトウェアの 基本操作を説明する。

上記(3に対応する 2 週目では，写真合成によるイメー ジ表現を行うことを前提に，画像処理ソフトを用いて， 画像の切り抜きや縮尺の合わせ方，レイヤーの使い方等 を説明し，実際に写真合成を体験させる。ここで実施す る課題 3 の制作においては, 頭の中に最終的なイメージ を思い浮かべ，そのイメージに近づいていくように各種 ッールを工夫しながらイメージ画像を描くように指導を 行った. 図 5 (a)に課題 3 で提出された作品のサンプルを 示す。

上記(4)に対応する 3 週目では, 課題 4 として建築パー スと風景の合成を実施させる。具体的には，建物の外観 を背景として想定される風景写真に合成する，内観パー スの空の外に見える風景を合成する，といった内容であ る。その際，周囲の環境との調和やイメージとの整合性 を図りながら魅力的な空間を見せるよう説明した。図 5 (b)に課題 4 で提出された作品のサンプルを示す. CAD 演習同様，優秀作品の発表を行い，授業全体での知識共 有を図っている。

3.2.4.レイアウト技法の講義・演習

レイアウト技法の講義・演習は 3 週（9コマ）で実施す

る $(7 \sim 9$ 週目).ここでの習得目標は次の通り.

(5) CAD によるデザインモデルと CGによる空間イメー ジの整合性を図り，デザインを完成できる (6) CAD・CGを用いて制作したモデルやイメージ画

像を 1 枚の紙面上で美しくレイアウトできる.

上記(5) (6)に対応するため， 7 週目の 2 コマで CADの 3 次元モデルを画像データに書き出したり, 画像データ を $\mathrm{CAD}$ 上に読み込んで $\mathrm{CAD}$ データとミックスしてレ 


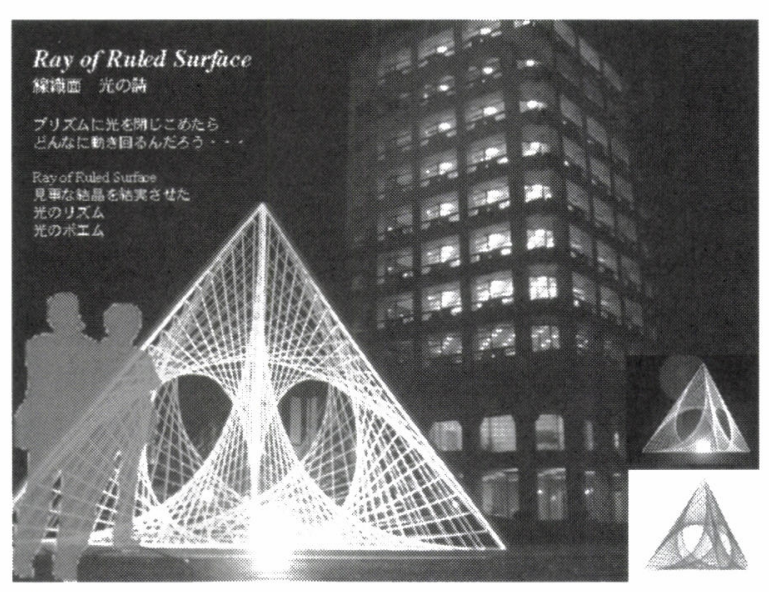

作品 1 : 線織面の光のオブジェを都市空間に配置した印象的 な夜景の表現

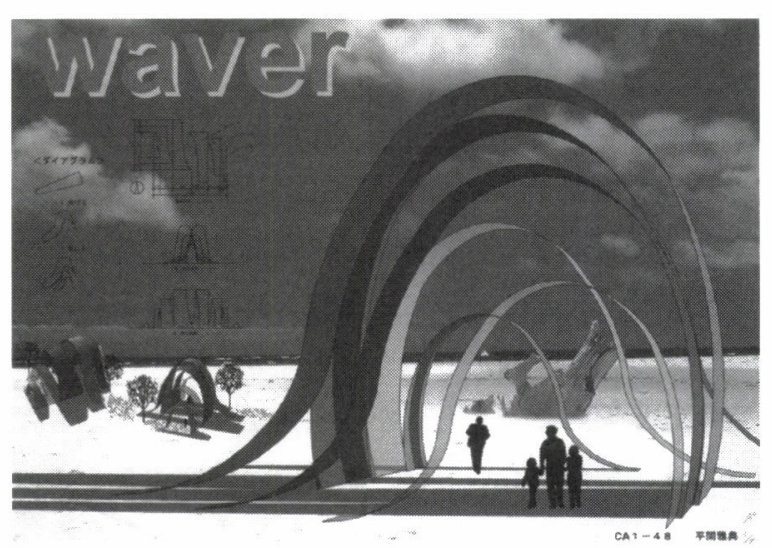

作品 2 : ウェーブで包まれる柔らかい空間と陰影が海岸のロ ケーションに生かされた表現

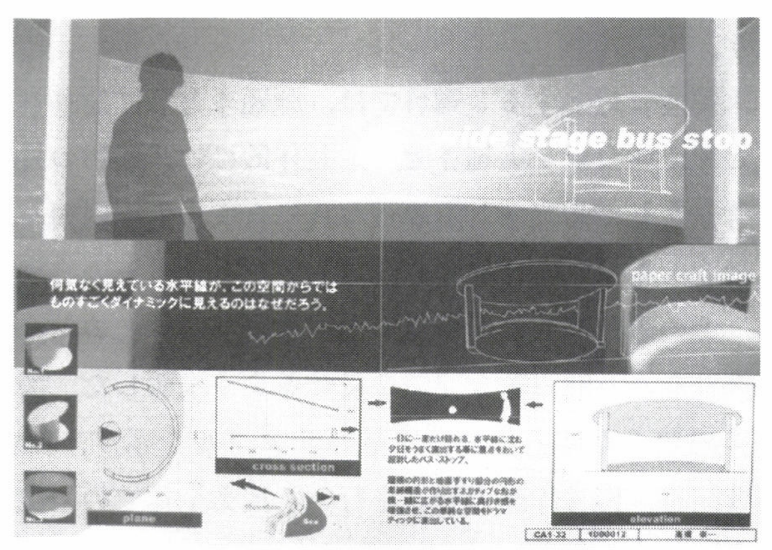

作品 3: 夕日の海岸風景が曲面状の建築オブジェにトリミン グされている内観の表現

図 $6 \mathrm{CAD} \cdot \mathrm{CG}$ を併用した最終課題プレゼンテーション

イアウトする方法などを説明する.

また上記6に対応するため, 7 週目の 1 コマで紙面デ ザインについて複数の作品事例を提示しながら具体的な 制作技法について解説する。最終課題（課題 5 ）の説明 もこの時に行い,これまでに習得した $\mathrm{CAD} \cdot \mathrm{CG}$ 技法 を駆使してスペースオブジェのデザインを紙面レイアウ トさせ，最終的なプレゼンテーションの制作を行うよう
指導する。この際，デザイン表現では感性的な側面の評 価も大きいため, 理知的な情報提示の枠組みを超えて感 覚的なプレゼンテーションを実施すること，紙面全体が 与える印象やインパクトも大切であり，コンセプトにあ わせて部分的な強調表現や余白のバランス・紙面を通じ たカラーリング・文字デザインなども表現操作するこ と，等を説明する.

図 6 に最終課題で優秀作品と評価された 3 点を示す。 いずれの作品についても，スペースオブジェと空間に対 するアイデアや豊かなイメージを表現できていると判断 する.プレゼンテーションも美しい仕上がりとなってい る.

\section{4. 授業評価と考察}

\section{1. 授業評価}

最終課題の作品群の評価を行った結果，昨年度（2003 年度）の同科目の作品群より空間表現のレベルが大幅に 向上していることが確認できた。これは個々の作品の質 からも一目瞭然であったが，表 3 に示す 4 段階評価（秀

表 3 2003年度と2004年度の成績分布

\begin{tabular}{|c|c|c|c|c|c|}
\hline & 秀 & 優 & 良 & 可 & 不可 \\
\hline 2003 年度 & $5 \%$ & $20 \%$ & $35 \%$ & $31 \%$ & $9 \%$ \\
\hline 2004 年度 & $5 \%$ & $32 \%$ & $45 \%$ & $5 \%$ & $12 \%$ \\
\hline
\end{tabular}

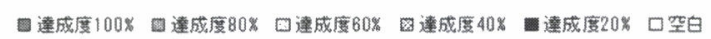

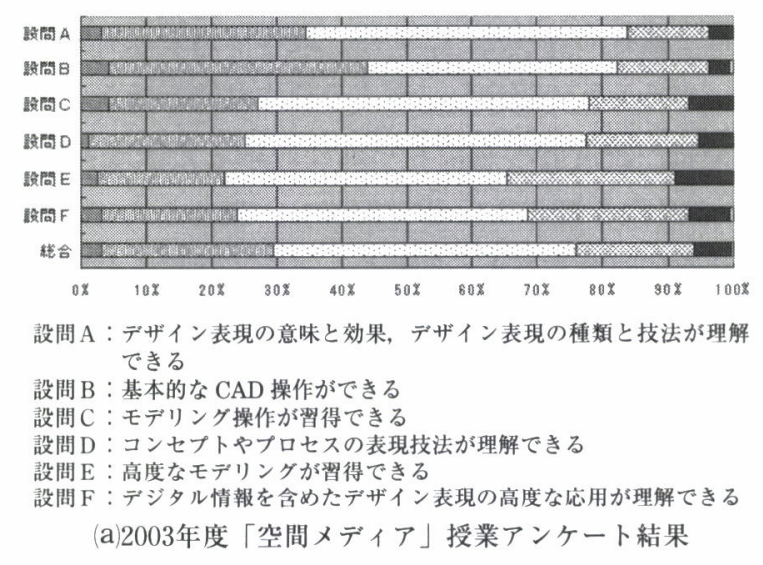

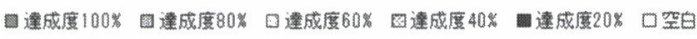

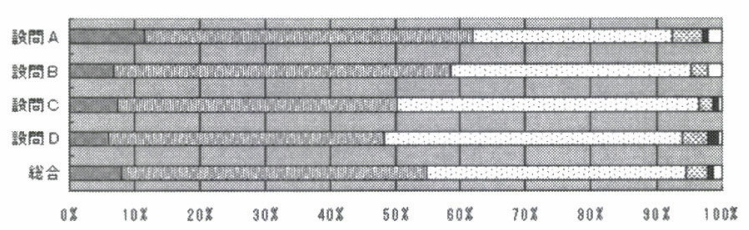

設問 $\mathrm{A} ： \mathrm{CAD}$ による建築図面が作成できる

設問 $\mathrm{B} ： \mathrm{CG}$ によるイメージ処理の操作ができる

設問 $\mathrm{C}$ ：デザイン表現技法が理解できる

設問 D : CAD - CG 併用によるデザイン表現が作成できる (b)2004年度「空間メディア」授業アンケート結果

図 7 2003年度と2004年度の授業アンケート結果 


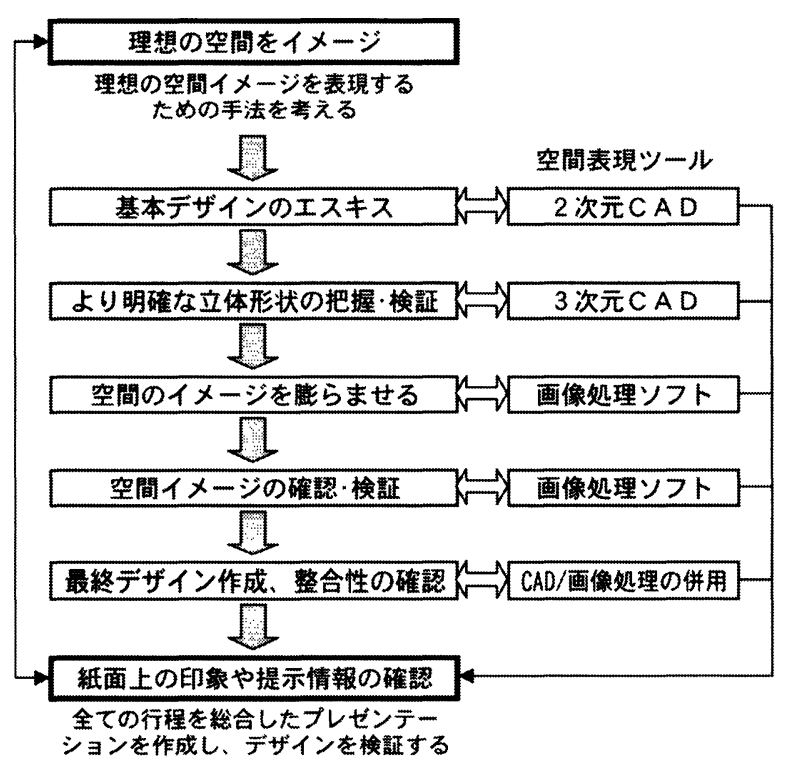

図 8 一連のデザイン思考と空間表現ツールの関係

〜可）の分布を比較しても高い評価を受けた学生の数が 明らかに増加していることが分かる.

図 7 は2003年度と2004年度の授業アンケートの結果で ある. アンケートの設問内容が変わっているため単純な 比較はできないが，2003年度では目標達成度が 6 割とい う学生が多数を占めているのに対し，2004年度は達成度 8 割と答えた学生の方が多いこと, 更には達成度 4 割以 下の学生が激減していることも大きな成果であると言え る. 2003 年度と 2004 年度の教員スタッフは全く同じ構成 である。最終課題の内容は設計の対象物が若干異なるも のの主旨は全く同じである.

\section{2. 考察}

学生の作品レベル，目標達成度を大幅に向上させた主 な要因として課題提出方式やソフトウェア環境の改善が 考えられる．以下にその詳細を述べる．

\subsection{1. デザイン思考と空間表現ツールの対応}

2003年度は中間課題と最終課題は全く独立したもので あったのに対し，2004年度はスペースオブジェのデザイ ンという一貫したテーマで CAD と CG の併用による空 間表現演習を実施した。一般的に，建築物の設計演習を 行う場合, 指導する側は最終的な成果物だけを期待し, 提出までの間，段階毎のデザイン思考のスキームや表現 手法などはほとんど指導しない，本科目では，一貫した 空間デザイン演習という点で同様の手法をとりながら も，その段階毎に検討すべき内容の大枠とそのための表 現手法をツールの操作方法と連動させ丁寧に指導する形 となっている（図 8 ）。このような方法をとることによ り，以前に比べてより感覚的・直接的にデザイン思考と
$\mathrm{CAD} \cdot \mathrm{CG}$ 操作を結びつけることができたのではないか と考えられる.

\subsection{2. ステップアップ式の課題提出方式}

上述した通り, 課題 $1 \sim 4$ は全て最終課題におけるス ペースオブジェのデザイン表現に必要な技術の獲得やデ ザイン検討を行うためのステップとした。このため，中 間課題は試行錯誤しながら空間デザインを進めていくた めの, 段階的な指導とデザインチェックの機会となり， その成果が最終課題における作品レベルの向上を促した と考えられる。

\subsection{3. ソフトウェア環境の改善}

2003年度までは図面作成や 3 次元モデリングの環境と して AutoCAD を使用してきた. AutoCAD は技術的な 設計図書作成には適しているが，本科目では感性的な側 面での空間表現や，そのための直感的なッールの操作環 境が求められる，2004年度は，初心者にも習得が容易な VectorWorks と SketchUPを導入したことにより，操 作方法の習得にとどまらず，デザインやその表現につい て十分に検討する余裕が生まれたのではないかと考えら れる。また，CAD データと画像データの連携が容易に とれる環境となったこと, 更にはその具体的な操作方法 を説明したことも課題作成における作業の効率化を促 し，デザイン検討時間の確保につながったと考えられ る.

\section{5 . まとめ}

本稿では，建築系授業「空間メディア」において新し く導入した $\mathrm{CAD} \cdot \mathrm{CG}$ による空間デザイン表現の演習 教育手法の有効性を明らかにするために，これまでの問 題点を把握した上で，2004年度授業で改善した内容を示 し, 学生の習得目標と講義・演習内容の対応関係を整理 した，更に，課題作品の成果物を紹介し，その質的向上 をもたらした要因について，デザイン思考と空間表現 ッールの関係，ステップアップ式の課題提出，ソフト ウェア環境の改善, という 3 つの点から考察を行った.

以上のことから, 図 8 に示すような一連のデザインプ ロセスに対応したステップアップ式の課題提出方式, 及 びそれに対応した空間表現ッールの段階的習得というス キームが，学生の空間イメージ表現技術の教育手法とし て効果的に㗢いていると考えられる．また，そのために は 3 次元モデルやイメージ画像の直感的な作図，及びそ れらの連携操作に容易に対応できるソフトウェア環境を 導入することもデザイン検討時間の確保の面から重要で あることも明らかとなった。 
現在，カリキュラム改変の過渡期であるため，今後は $\mathrm{CAD}$ 演習の 2 次元表現の部分を 2 年次開講の「建築 $\mathrm{CAD}$ 演習」において前倒しで実施し，「空間メディア」 では 3 次元的なデザイン思考の徹底，および光と影によ る空間表現のための 3 次元 CG の導入も進めていきたい と考えている.

\section{参考文献}

［1］阿部浩和, 吉田勝行, “図学実習課題と体験的授業”, 図学研究, 第37巻 1 号 (2003), 3-8.

［2］和田浩一 他 3 名, “設計教育における準実験的試み 一「場面」設定が設計に与える影壀—”, 日本建築学 会計画系論文集 NO. 516(1999), 145-151.

［3］和田浩一他 4 名, “ 3 D-CAD を用いた設計手法に関 する研究一設計教育における準実験的試みその 2 一”, 日本建築学会計画系論文集 NO. 549 (2001), 169176.

[4] 建築学情報教育研究委員会, 授業改善のための IT 活 用, 社団法人私立大学情報教育協会 (2001), 163-173.

[ 5 ] GA HOUSE Vol. 59, A. D. A. EDITA Tokyo (1999), 150.

[ 6 ] GA HOUSE Vol. 59, A. D. A. EDITA Tokyo (1999), 87.

2005年 1 月25日受付

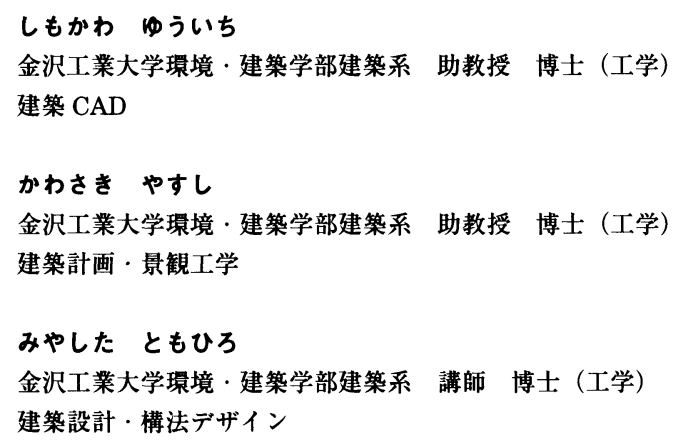

